\title{
Non-surgical skin tightening
}

\author{
Kelly O'Connor ${ }^{1}$, Prasanthi Kandula ${ }^{2}$, Michael Kaminer ${ }^{2}$ \\ 1Department of Dermatology, Boston University, Boston, MA 02118, USA. \\ ${ }^{2}$ Department of Dermatology, SkinCare Physicians, Chestnut Hill, MA 02467, USA.
}

Correspondence to: Dr. Prasanthi Kandula, Department of Dermatology, SkinCare Physicians, Chestnut Hill, MA 02467, USA. E-mail: pkandula@skincarephysicians.net

How to cite this article: O'Connor K, Kandula P, Kaminer M. Non-surgical skin tightening. Plast Aesthet Res 2021;8:64. https://dx.doi.org/10.20517/2347-9264.2021.60

Received: 9 Jun 2021 First Decision: 6 Jul 2021 Revised: 28 Jul 2021 Accepted: 3 Nov 2021 Published: 20 Dec 2021

Academic Editor: Wen-Guo Cui Copy Editor: Xi-Jun Chen Production Editor: Xi-Jun Chen

\begin{abstract}
Skin laxity is an unavoidable consequence of aging and chronic sun exposure. Patients are increasingly turning to non-surgical skin tightening measures for a more youthful look. Non-surgical methods can be effective in treating mild to moderate skin laxity, while offering decreased downtimes and fewer serious complications than surgical interventions. This article reviews the major non-surgical interventions for skin laxity: ablative and non-ablative lasers, radiofrequency, and microfocused ultrasound, noting their physiologic mechanism of actions, clinical benefits, and side effects. Regardless of the procedure, patient selection and expectation setting are crucial to achieving desired results and ensuring patient satisfaction.
\end{abstract}

Keywords: Skin tightening, ablative, non-ablative, radiofrequency, microfocused ultrasound

\section{INTRODUCTION}

Skin laxity and the appearance of fine lines and wrinkles are inevitable results of aging and chronic sun exposure. Patients often turn to skin tightening measures for a more youthful look. Non-surgical methods of skin tightening have grown popular over the past few decades because they are effective in treating mild to moderate skin laxity, offer decreased downtimes, and carry a lower risk of complications, as compared to surgical interventions ${ }^{[1]}$. This chapter aims to review the major non-surgical interventions for skin laxity: ablative and non-ablative lasers, radiofrequency (RF), and microfocused ultrasound (MFU). These interventions provide skin rejuvenation through a shared overarching biochemical mechanism; they heat 
the dermis to a temperature that stimulates the reorganization of existing collagen fibers and the generation of new fibers.

The aging process:

The dermis of the skin is comprised mainly of fibroblasts and extracellular matrix $(\mathrm{ECM})^{[2]}$. Fibroblasts are responsible for the synthesis of collagen fibers, elastic fibers, and amorphous matrix proteins (such as proteoglycans and glycosaminoglycans), which are deposited in the ECM. The contours and fullness of the skin are a result of the tightly wound, triple helical structure of collagen fibers, and the absorption of water by amorphous proteins ${ }^{[3]}$. The elastic fibers are responsible for returning the skin to its normal structure after being stretched or deformed ${ }^{[4]}$.

During the process of aging, there is a net loss of collagen due to decreased synthesis by fibroblasts and increased degradation by matrix metalloproteinases (MMPs) ${ }^{[5-7]}$. The increased activity of MMPs is a result of the rise in reactive oxygen species, which is accelerated by sun exposure ${ }^{[8,9]}$. Collagen fibrils themselves gradually become more fragmented and haphazardly arranged over time $e^{[10,11]}$ and lead to skin laxity ${ }^{[12]}$. While the number of elastic fibers in the papillary dermis actually increases with photoaging, in a process known as solar elastosis, their coarse and disorganized pattern renders them non-functional ${ }^{[13]}$. Decreased tissue elasticity contributes to skin laxity and wrinkle formation ${ }^{[14]}$.

Skin tightening techniques target collagen and elastic fiber remodeling and synthesis to rejuvenate the skin. Interventional devices heat the dermis to a temperature that unravels the intramolecular hydrogen bonds that connect collagen fibers, allowing them to reorganize and contract into more tightly arranged form $s^{[15-17]}$. The increased temperature also stimulates neocollagenesis by increasing fibroblast growth and production $^{[18]}$. This process takes place over weeks to months and accounts for the enhanced clinical results observed months after treatment. RF and MFU have also been shown to improve the structure of existing elastic fibers and stimulate the production of new ones ${ }^{[1,20]}$.

\section{NON-SURGICAL INTERVENTIONS [Table 1]}

\section{Ablative lasers}

Fully (non-fractionated) ablative lasers were among the first non-surgical interventions for skin tightening ${ }^{[21]}$. The carbon dioxide $\left(\mathrm{CO}_{2}\right)$ laser targets the chromophore water, which is found in both the epidermis and dermis ${ }^{[2,22]}$. Therefore, their use leads to damage of the entire epidermis and superficial dermis. This widespread damage evokes a change in the cytokine milieu and stimulates neocollagenesis ${ }^{[23]}$, resulting in improvement in the appearance of rhytids ${ }^{[24-26]}$. However, it also leads to significant pain and erythema for patients ${ }^{[27]}$. The downtime associated with this type of laser made fractionated lasers a more sought-after intervention.

Fractionation of the laser beam divides the laser beam into vertical microcolumns to create smaller, more focused beams. The laser then penetrates the tissue in a grid-like fashion ${ }^{[28,29]}$, sparing the majority of the treated surface from ablation. The unaffected tissue can provide growth factors and fibroblasts to the damaged microcolumns of tissue to assist in faster wound healing, as compared to non-fractionated ablative lasers ${ }^{[2,30]}$. Fractionated $\mathrm{CO}_{2}$ lasers have been shown to be effective in the treatment of photoaging after 2-3 treatments in lighter skin types ${ }^{[31]}$. While fractionation was important in the evolution of lasers, side effects of dyspigmentation, bacterial infections, persistent erythema, and atrophic scarring limit its use ${ }^{[25,27]}$. Dyspigmentation is more prevalent in dark skin types ${ }^{[32]}$, and different modalities are often employed in these patients. 
Table 1. Overview of non-surgical techniques

\begin{tabular}{|c|c|c|c|c|}
\hline & $\begin{array}{l}\text { Primary } \\
\text { indication(s) }\end{array}$ & Mechanism of action & Advantages & Disadvantages \\
\hline Ablative lasers & $\begin{array}{l}\text { Moderate to deep } \\
\text { rhytids and scars }\end{array}$ & $\begin{array}{l}\text { Destruction of the chromophore } \\
\text { water (present in the epidermis and } \\
\text { dermis) }\end{array}$ & $\begin{array}{l}\text { Effective at treating deep } \\
\text { rhytids and scars }\end{array}$ & $\begin{array}{l}\text { Significant downtime } \\
\text { High risk of dyspigmentation, } \\
\text { especially in darker skin types }\end{array}$ \\
\hline $\begin{array}{l}\text { Non-ablative } \\
\text { lasers }\end{array}$ & $\begin{array}{l}\text { Mild to moderate } \\
\text { rhytids and scars }\end{array}$ & $\begin{array}{l}\text { Selective destruction of } \\
\text { chromophores in the dermis }\end{array}$ & $\begin{array}{l}\text { Minimal downtime } \\
\text { Homogenizes color and } \\
\text { texture of skin } \\
\text { Safe to use in variety of skin } \\
\text { types }\end{array}$ & $\begin{array}{l}\text { Not shown to be very effective } \\
\text { in skin tightening }\end{array}$ \\
\hline Radiofrequency & Skin tightening & $\begin{array}{l}\text { Heating of tissue with } \\
\text { electrothermal energy in the form of } \\
\text { an oscillating current }\end{array}$ & $\begin{array}{l}\text { Minimal downtime } \\
\text { Well tolerated } \\
\text { Shown to be effective for } \\
\text { skin tightening of face and } \\
\text { neck } \\
\text { Can be combined with } \\
\text { microneedling }\end{array}$ & $\begin{array}{l}\text { Mild discomfort during } \\
\text { procedure }\end{array}$ \\
\hline $\begin{array}{l}\text { Microfocused } \\
\text { ultrasound }\end{array}$ & $\begin{array}{l}\text { Skin tightening } \\
\text { Destruction of solid } \\
\text { tumors }\end{array}$ & $\begin{array}{l}\text { Heating of tissue with a } \\
\text { concentrated beam of ultrasound } \\
\text { waves }\end{array}$ & $\begin{array}{l}\text { Shown to be effective for } \\
\text { skin tightening of face and } \\
\text { neck } \\
\text { Different probes can target } \\
\text { different depths of the skin }\end{array}$ & $\begin{array}{l}\text { Mild to moderate discomfort } \\
\text { during procedure } \\
\text { May have pain and bruising } \\
\text { afterwards }\end{array}$ \\
\hline
\end{tabular}

In our practice, fully ablative Erbium: Yttrium Aluminium Garnet and fractional $\mathrm{CO}_{2}$ are used primarily for resurfacing moderate to severe rhytids and scarring. While some tissue tightening can be seen in these patients, we do not use this method for patients primarily interested in skin tightening because it is limited by the length of downtime, wound care, and postprocedure erythema ${ }^{[27]}$.

\section{Non-ablative lasers}

Non-ablative lasers, such as 1550-nm Erbium and picosecond devices, target chromophores in the dermis, which allows the epidermis to remain unaffected and largely intact. These lasers can initiate collagen shrinking and the formation of new fibers with similar mechanisms to ablative lasers, but with shorter downtimes and fewer side effects ${ }^{[33]}$. One study of 50 patients demonstrated significant improvement in photodamaged skin and mild-moderate rhytids with 3 treatment sessions of 1550-nm Erbium-doped fiber laser at 3-4 weeks intervals, without complications of dyspigmentation or scarring ${ }^{[34]}$. The 1550-nm Erbium laser is a very popular procedure amongst our patients. After a series of treatments, patients can achieve an overall improvement in their photodamage, rhytids, and texture with minimal downtime. Some tissue tightening can also be seen in these patients; however, we do not use this method for patients primarily interested in skin tightening. Furthermore, several of our laser colleagues have been using the $755-\mathrm{nm}$ picosecond to perform the "picotoning" procedure. Picotoning is the use of a picosecond laser at low fluences to improve skin texture and create a more uniform color tone. It has been shown to improve melasma $^{[35]}$, photodamage ${ }^{[36]}$, and acne $\operatorname{scars}^{[37]}$, but it has not been demonstrated to produce reliable skin tightening.

\section{Radiofrequency}

RF uses the emission of a high-frequency oscillating current that flows from an electrode tip to the target tissue $^{[38]}$. In contrast to lasers, it is a chromophore independent process. The tissue is heated by electrothermal energy, which is generated from the electrical current meeting resistance in the tissue. The formula Ohm's Law states that current is proportional to the voltage of the device and inversely to the resistance (or impedance) of the tissue across two points of flow. The electrothermal energy that is generated by RF has been shown to result in collagen contraction, reorganization, and synthesis ${ }^{[39,40]}$. It also decreases the amount of abnormally accumulated elastin fibers in the papillary dermis, while restoring the 
structure of the remaining elastic fibers ${ }^{[19]}$.

RF devices differ in their configuration of electrodes. A monopolar RF device emits an electrical current directly onto the skin and recycles it back through a grounding pad ${ }^{[41]}$. A bipolar device emits current between two electrodes that are adjacently placed on the skin at a fixed distance. Major benefits of monopolar RF devices include their ability to penetrate deep into the subcutaneous fat and volumetrically tighten the tissue ${ }^{[4]}$. Devices like Thermage are able to selectively heat fibrous septae within the fat (due to differences in tissue resistance), leading to immediate contraction of fibers and new collagen deposition ${ }^{[42]}$ [Figures 1-3]. Studies have demonstrated the efficacy of monopolar devices tightening tissue across the face and neck ${ }^{[42-44]}$, and increased benefit with multiple passes ${ }^{[45]}$. This method does require significant cooling before and during the procedure to prevent burning of the epidermis. Bipolar devices offer a more controlled stream of current but are limited in their depth of penetration to approximately one-half of the distance between electrodes. Several studies have also supported their efficacy and low side effects profile $^{[46,47]}$.

While the depth of penetration in radiofrequency is influenced by polarity, it is also dependent on the tissue type, current frequency, and tissue temperature ${ }^{[48]}$. Therefore, in order to overcome the problem of penetration depth, additional methods and tools have been designed to exploit these other parameters. For example, since tissue resistance is inversely proportional to temperature, preheating the target tissue before treatment increases conductivity ${ }^{[49]}$. The increased conductivity allows for lower voltage settings, resulting in less pain and postoperative complications. Conversely, cooling the surface of the skin during treatment avoids current dispersion and heat loss in the epidermis, allowing for more current to be directed into the $\operatorname{dermis}^{[50]}$.

Vacuum assist devices are also utilized to increase conductivity in the dermis. A vacuum on a bipolar device suctions a fold of tissue between the two electrodes to decrease the distance the current has to travel ${ }^{[51]}$. The vacuum itself may also provide additional collagen stimulation by increasing blood flow and mechanical compression $^{[51]}$.

Finally, RF devices can use microneedling to bypass the epidermis and deliver electrical current directly to the dermis ${ }^{[52]}$. Microneedling devices use different needle densities and widths, while the needle depth can be adjusted on each device ${ }^{[52]}$. This type of treatment has been shown to increase reticular dermal volume, cellularity, hyaluronic acid, and elastin ${ }^{[33]}$. Devices also differ in the needle tips, which can be insulated or non-insulated. Insulation consists of a non-conductive coating that lasts the length of the epidermis. It is thought to be paramount in sparing the epidermis because the current is not emitted until the dermis. However, insulated needles require multiple passes to treat the dermis at various depths ${ }^{[54,55]}$. Furthermore, it has been shown that non-insulated microneedling RF devices improve skin texture without causing dyspigmentation or epidermal burns ${ }^{[56]}$. Microneedling RF with non-insulated needles has even been shown to be safe in skin types III to $\mathrm{V}$ after multiple treatments for acne scars ${ }^{[57]}$. Another advantage of noninsulated needles is that they allow for more effective heating and coagulation of vessels in the dermis ${ }^{[58,59]}$.

Clearly, the application of radiofrequency for skin tightening is effective, as evidenced by the broad variety of treatment options available for skin tightening that employ RF. However, many of the currently available devices and procedures have failed to live up to some of the hype surrounding them. While microneedling RF shows theoretical promise, we have been unable to consistently replicate the skin tightening benefits reported by some. This comes after working with more than a half-dozen devices, all claiming to produce superior skin tightening. In the end, we continue to utilize monopolar RF (Thermage) as our preferred skin 


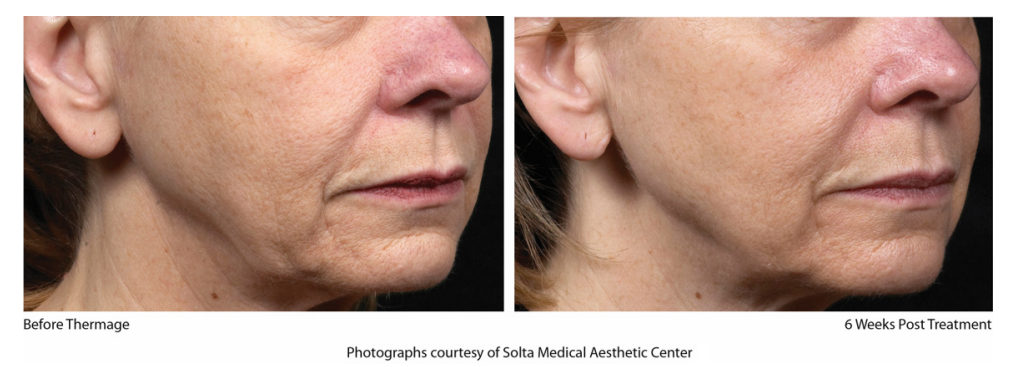

Figure 1. Before and after pictures of a patient treated with Thermage to the lower face.

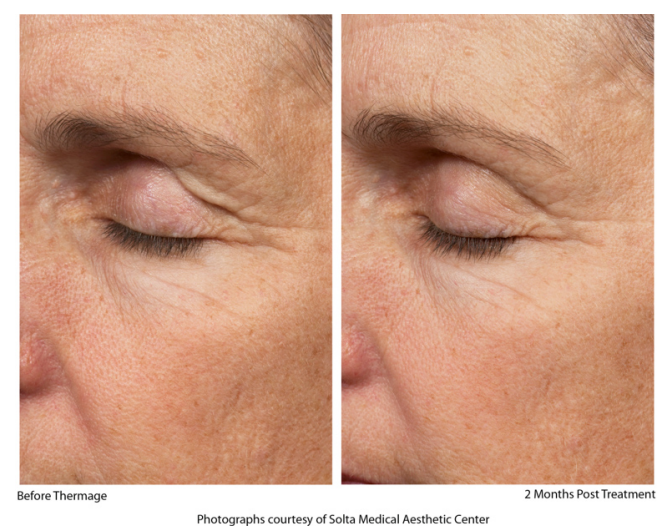

Figure 2. Before and after pictures of a patient treated with Thermage to the upper eyebrow.

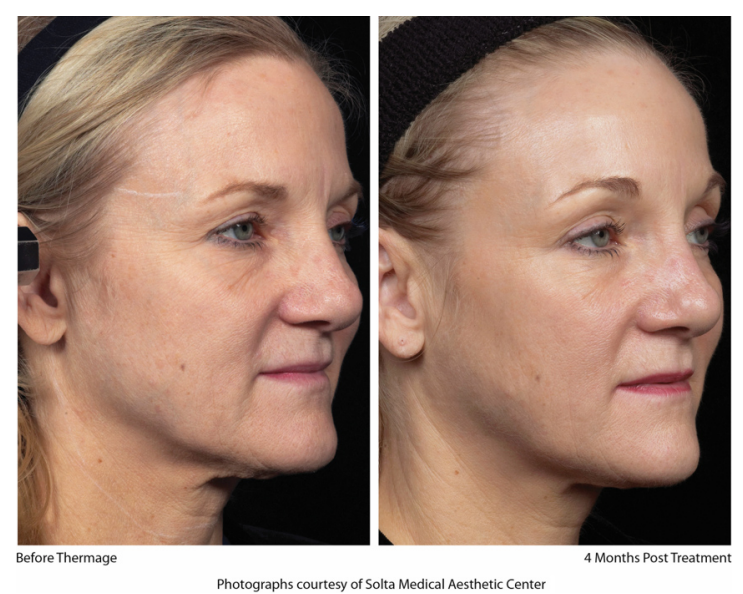

Figure 3. Before and after pictures of a patient treated with Thermage to the full face.

tightening treatment for the face and body. For smaller areas, such as the periorbital area, we often utilize more focal RF (Pelleve) in a series of 2-3 monthly treatments, with annual maintenance treatments.

\section{Microfocused ultrasound}

MFU uses a transducer to emit concentrated beams of ultrasound waves ${ }^{[60]}$. These waves generate molecular vibrations, and subsequently heat, in a precise treatment area to over $65{ }^{\circ} \mathrm{C}$ in milliseconds ${ }^{[60]}$. The repetitive compressions and rarefactions of tissue from the energy waves also create shearing forces on a molecular level ${ }^{[6]}$, further raising the tissue temperature. Coagulation necrosis and cavitation of the targeted tissue can 
occur under high-energy settings and long treatment durations ${ }^{[62]}$. These properties were desired in its initial application in the treatment of solid internal tumors, such as prostate cancer or uterine fibroids ${ }^{[63]}$. The technology can be used at lower energy levels and lower frequencies to target the dermis and facial superficial musculoaponeurotic system (SMAS) ${ }^{[6,65]}$. The SMAS is a network of fibrous septa that connect the dermis to facial muscles ${ }^{[64]}$. MFU stimulates contraction of the SMAS ${ }^{[64]}$ and deposition of new collagen and elastic fibers in the deep reticular dermis ${ }^{[20]}$, resulting in tighter skin of the face and neck ${ }^{[65]}$.

Each device has a transducer that delivers ultrasound waves through a probe at a fixed frequency ${ }^{[38]}$. Probes with higher frequencies are used for superficial tissues, such as the neck and eyebrow, while lower frequencies are used for deeper tissues, such as the cheeks and submental region ${ }^{[6]}$. The adjustable parameters are the energy setting and duration of the beam. Advantages to this technology include increased depth of penetration, preservation of the epidermis, and decreased loss of energy in lateral tissue planes ${ }^{[6]]}$. Efficacy of skin tightening has been demonstrated on the face and neck, including the infraorbital cheeks $^{[67]}$, nasolabial folds and jaw lines ${ }^{[68]}$, and eyebrows ${ }^{[69]}$.

Sofwave is a new iteration of MFU technology that focuses on a more superficial depth ${ }^{[70]}$. It received Food \& Drug Administration (FDA) approval in 2019 for the indicated use as a non-invasive dermatological aesthetic treatment to improve facial lines and wrinkles $^{[70]}$. In the clinical study submitted to the FDA, blinded reviewers saw that $78 \%$ of the treated subjects had a reduction in a solar elastosis score for perioral and periorbital regions. $72 \%$ of the subjects reported improvement in their wrinkle appearance. There were no device-related adverse events, and no subjects withdrew from the study due to pain or discomfort ${ }^{[70]}$. However, there is a lack of published clinical data on this product, so larger, peer reviewed studies are needed to better assess this device.

The most common side effects of MFU are transient pain, erythema, edema, and bruising, which typically last for a few days ${ }^{[6,7] 1]}$. A study of 49 patients of Fitzpatrick skin type III to IV observed 2 cases of postinflammatory hyperpigmentation on the forehead at 1 month, but not at 6 months ${ }^{[71]}$. Nerve and bone irritation are rarely encountered, as the frequency of the transducer fixes the depth of penetration.

Monopolar radiofrequency (MRF) and MFU have emerged as two of the preferred methods for skin tightening of the face and neck due to their efficacy, favorable side effect profile, and preservation of the epidermis. A prospective, split-face and neck, evaluator-blinded clinical trial directly compared MRF (Thermage) against MFU (Ulthera) in 20 patients ${ }^{[72]}$. The study showed significant improvement in face and neck laxity as soon as 30 days after each treatment. There were no statistical differences between MRF and MFU in improvement measures of skin laxity, patient satisfaction, or adverse events.

In our experience, our patients better tolerate MRF, and it has become our treatment of choice for mild to moderate skin laxity of the face and neck. MFU is clearly an effective skin tightening treatment and is used quite successfully by many clinicians, but the pain associated with this procedure is prohibitive for our patients. Further, recent reports of significant side effects with $\mathrm{MFU}^{[6]}$ have reinforced to our patients the safety and tolerability advantages we believe MRF holds over MFU.

\section{Contraindications}

It should be noted that contraindications to all of the above treatments include the presence of malignancies, open wounds, and implanted devices (e.g., pacemakers and defibrillators), in the field of treatment. Pregnancy is also a contraindication, as a lack of sufficient studies in this population has been performed. 


\section{CONCLUSION}

Surgical intervention remains the gold standard of treatment for skin laxity. While non-surgical skin tightening technologies have gained popularity, they historically have not achieved the same levels of treatment durability and efficacy. For any skin tightening treatment, patient selection is crucial to achieving desired results and ensuring patient satisfaction. Maximal results are gradual and appear over three to six months. Most patients show a mild to moderate improvement in the appearance of laxity. In our experience, younger patients with mild to moderate skin laxity have better clinical outcomes than older patients with severe laxity and rhytids. We recommend patients have skin tightening procedures every one to two years, for both preventive and therapeutic measures. MRF is our treatment of choice due to its low pain level during treatment, consistent results, positive patient experience, and track record of greater than $95 \%$ patient satisfaction for over 20 years.

\section{DECLARATIONS}

\section{Authors' contributions}

Contributed to the scope and format of the review: O'Connor K, Kandula P, Kaminer M

Took the lead in writing the manuscript: O'Connor $\mathrm{K}$

Providing substantial guidance and editing: Kandula P, Kaminer M

\section{Availability of data and materials}

Not applicable.

\section{Financial support and sponsorship}

None.

\section{Conflicts of interest}

Dr. Kaminer is a consultant for the following entities: Solta, Arctic Fox, Allergan, Endo, Soliton, and NC8. Other authors declared that there are no conflicts of interest.

\section{Ethical approval and consent to participate}

Not applicable.

\section{Consent for publication}

The figures are obtained copyright permission.

\section{Copyright}

(c) The Author(s) 2021.

\section{REFERENCES}

1. Mazzoni D, Lin MJ, Dubin DP, Khorasani H. Review of non-invasive body contouring devices for fat reduction, skin tightening and muscle definition. Australas J Dermatol 2019;60:278-83. DOI PubMed

2. Cole MA, Quan T, Voorhees JJ, Fisher GJ. Extracellular matrix regulation of fibroblast function: redefining our perspective on skin aging. J Cell Commun Signal 2018;12:35-43. DOI PubMed PMC

3. Fleischmajer R, Perlish JS, Timpl R. Collagen fibrillogenesis in human skin. Ann N Y Acad Sci 1985;460:246-57. DOI PubMed

4. Gosline J, Lillie M, Carrington E, Guerette P, Ortlepp C, Savage K. Elastic proteins: biological roles and mechanical properties. Philos Trans R Soc Lond B Biol Sci 2002;357:121-32. DOI PubMed PMC

5. Varani J, Dame MK, Rittie L, et al. Decreased collagen production in chronologically aged skin: roles of age-dependent alteration in fibroblast function and defective mechanical stimulation. Am J Pathol 2006;168:1861-8. DOI PubMed PMC

6. Fisher GJ, Varani J, Voorhees JJ. Looking older: fibroblast collapse and therapeutic implications. Arch Dermatol 2008;144:666-72. DOI PubMed PMC

7. Quan T, Shao Y, He T, Voorhees JJ, Fisher GJ. Reduced expression of connective tissue growth factor (CTGF/CCN2) mediates collagen loss in chronologically aged human skin. J Invest Dermatol 2010;130:415-24. DOI PubMed PMC

8. Stadtman ER. Protein oxidation and aging. Science 1992;257:1220-4. DOI PubMed 
9. Golden TR, Hinerfeld DA, Melov S. Oxidative stress and aging: beyond correlation. Aging Cell 2002;1:117-23. DOI PubMed

10. Fisher GJ, Shao Y, He T, et al. Reduction of fibroblast size/mechanical force down-regulates TGF- $\beta$ type II receptor: implications for human skin aging. Aging Cell 2016;15:67-76. DOI PubMed PMC

11. Fisher GJ, Quan T, Purohit T, et al. Collagen fragmentation promotes oxidative stress and elevates matrix metalloproteinase-1 in fibroblasts in aged human skin. Am J Pathol 2009;174:101-14. DOI PubMed PMC

12. Fisher GJ, Wang ZQ, Datta SC, Varani J, Kang S, Voorhees JJ. Pathophysiology of premature skin aging induced by ultraviolet light. N Engl J Med 1997;337:1419-28. DOI PubMed

13. Weihermann AC, Lorencini M, Brohem CA, de Carvalho CM. Elastin structure and its involvement in skin photoageing. Int $J$ Cosmet Sci 2017;39:241-7. DOI PubMed

14. Naylor EC, Watson RE, Sherratt MJ. Molecular aspects of skin ageing. Maturitas 2011;69:249-56. DOI PubMed

15. Alster TS, Lupton JR. Nonablative cutaneous remodeling using radiofrequency devices. Clin Dermatol 2007;25:487-91. DOI PubMed

16. Liu H, Dang Y, Wang Z, Chai X, Ren Q. Laser induced collagen remodeling: a comparative study in vivo on mouse model. Lasers Surg Med 2008;40:13-9. DOI PubMed

17. Longo C, Galimberti M, De Pace B, Pellacani G, Bencini PL. Laser skin rejuvenation: epidermal changes and collagen remodeling evaluated by in vivo confocal microscopy. Lasers Med Sci 2013;28:769-76. DOI PubMed

18. Hayashi K, Thabit G 3rd, Massa KL, et al. The effect of thermal heating on the length and histologic properties of the glenohumeral joint capsule. Am J Sports Med 1997;25:107-12. DOI PubMed

19. el-Domyati M, el-Ammawi TS, Medhat W, et al. Radiofrequency facial rejuvenation: evidence-based effect. $J$ Am Acad Dermatol 2011;64:524-35. DOI PubMed PMC

20. Suh DH, Choi JH, Lee SJ, Jeong KH, Song KY, Shin MK. Comparative histometric analysis of the effects of high-intensity focused ultrasound and radiofrequency on skin. J Cosmet Laser Ther 2015;17:230-6. DOI PubMed

21. Kaplan I. The CO2 surgical laser. Photomed Laser Surg 2010;28:847-8. DOI PubMed

22. Anderson RR, Parrish JA. Selective photothermolysis: precise microsurgery by selective absorption of pulsed radiation. Science 1983;220:524-7. DOI PubMed

23. Orringer JS, Sachs DL, Shao Y, et al. Direct quantitative comparison of molecular responses in photodamaged human skin to fractionated and fully ablative carbon dioxide laser resurfacing. Dermatol Surg 2012;38:1668-77. DOI PubMed

24. Alster TS, Garg S. Treatment of facial rhytides with a high-energy pulsed carbon dioxide laser. Plast Reconstr Surg 1996;98:791-4. DOI PubMed

25. Ward PD, Baker SR. Long-term results of carbon dioxide laser resurfacing of the face. Arch Facial Plast Surg 2008;10:238-43; discussion 244-5. DOI PubMed

26. Waldorf HA, Kauvar AN, Geronemus RG. Skin resurfacing of fine to deep rhytides using a char-free carbon dioxide laser in 47 patients. Dermatol Surg 1995;21:940-6. DOI PubMed

27. Nanni CA, Alster TS. Complications of carbon dioxide laser resurfacing. An evaluation of 500 patients. Dermatol Surg 1998;24:31520. DOI PubMed

28. Manstein D, Herron GS, Sink RK, Tanner H, Anderson RR. Fractional photothermolysis: a new concept for cutaneous remodeling using microscopic patterns of thermal injury. Lasers Surg Med 2004;34:426-38. DOI PubMed

29. Laubach HJ, Tannous Z, Anderson RR, Manstein D. Skin responses to fractional photothermolysis. Lasers Surg Med 2006;38:142-9. DOI PubMed

30. Hantash BM, Bedi VP, Kapadia B, et al. In vivo histological evaluation of a novel ablative fractional resurfacing device. Lasers Surg Med 2007;39:96-107. DOI PubMed

31. Tierney EP, Hanke CW. Fractionated carbon dioxide laser treatment of photoaging: prospective study in 45 patients and review of the literature. Dermatol Surg 2011;37:1279-90. DOI PubMed

32. Alster T, Hirsch R. Single-pass $\mathrm{CO}_{2}$ laser skin resurfacing of light and dark skin: extended experience with 52 patients. $J$ Cosmet Laser Ther 2003;5:39-42. PubMed

33. Preissig J, Hamilton K, Markus R. Current laser resurfacing technologies: a review that delves beneath the surface. Semin Plast Surg 2012;26:109-16. DOI PubMed PMC

34. Wanner M, Tanzi EL, Alster TS. Fractional photothermolysis: treatment of facial and nonfacial cutaneous photodamage with a 1,550nm erbium-doped fiber laser. Dermatol Surg 2007;33:23-8. DOI PubMed

35. Kim DG, Nam SM, Shin JS, Park ES. Effectiveness of the pico-toning technique for the treatment of melasma with a low fluence 1,064-nm Nd:YAG laser in Asian patients. Medical Lasers 2020;9:166-71. DOI

36. Saluja R. Evaluation of the safety and efficacy of a low fluence, picopulsed, alexandrite laser in a pico-toning technique with a diffractive lens optic for the treatment of photodamage and textural improvement in "off the face" applications. J Drugs Dermatol 2016;15:1398-1401. PubMed

37. Brauer JA, Kazlouskaya V, Alabdulrazzaq H, et al. Use of a picosecond pulse duration laser with specialized optic for treatment of facial acne scarring. JAMA Dermatol 2015;151:278-84. DOI PubMed

38. Hinshaw JL, Lubner MG, Ziemlewicz TJ, Lee FT Jr, Brace CL. Percutaneous tumor ablation tools: microwave, radiofrequency, or cryoablation--what should you use and why? Radiographics 2014;34:1344-62. DOI PubMed PMC

39. Zelickson BD, Kist D, Bernstein E, et al. Histological and ultrastructural evaluation of the effects of a radiofrequency-based nonablative dermal remodeling device: a pilot study. Arch Dermatol 2004;140:204-9. DOI PubMed

40. Kist D, Burns AJ, Sanner R, Counters J, Zelickson B. Ultrastructural evaluation of multiple pass low energy versus single pass high 
energy radio-frequency treatment. Lasers Surg Med 2006;38:150-4. DOI PubMed

41. Wollina U. Treatment of facial skin laxity by a new monopolar radiofrequency device. J Cutan Aesthet Surg 2011;4:7-11. DOI PubMed PMC

42. Fitzpatrick R, Geronemus R, Goldberg D, Kaminer M, Kilmer S, Ruiz-Esparza J. Multicenter study of noninvasive radiofrequency for periorbital tissue tightening. Lasers Surg Med 2003;33:232-42. DOI PubMed

43. Hsu TS, Kaminer MS. The use of nonablative radiofrequency technology to tighten the lower face and neck. Semin Cutan Med Surg 2003;22:115-23. DOI PubMed

44. Alster TS, Tanzi E. Improvement of neck and cheek laxity with a nonablative radiofrequency device: a lifting experience. Dermatol Surg 2004;30:503-7; discussion 507. DOI PubMed

45. Dover JS, Zelickson B; 14-Physician Multispecialty Consensus Panel. Results of a survey of 5,700 patient monopolar radiofrequency facial skin tightening treatments: assessment of a low-energy multiple-pass technique leading to a clinical end point algorithm. Dermatol Surg 2007;33:900-7. DOI PubMed

46. Bloom BS, Emer J, Goldberg DJ. Assessment of safety and efficacy of a bipolar fractionated radiofrequency device in the treatment of photodamaged skin. $J$ Cosmet Laser Ther 2012;14:208-11. DOI PubMed

47. Montesi G, Calvieri S, Balzani A, Gold MH. Bipolar radiofrequency in the treatment of dermatologic imperfections: clinicopathological and immunohistochemical aspects. J Drugs Dermatol 2007;6:890-896. PubMed

48. Melia G. Electromagnetic absorption by the human body from 1 - 15 GHz. Available from: https://etheses.whiterose.ac.uk/4676/ [Last accessed on 2 Dec 2021].

49. Duncan DI, Kreindel M. Basic radiofrequency: physics and safety and application to aesthetic medicine. In: Lapidoth M, Halachmi S, editors. Radiofrequency in cosmetic dermatology. Basel: Karger; 2015. p. 1-22. DOI

50. Blaufox AD, Numan MT, Laohakunakorn P, Knick B, Paul T, Saul JP. Catheter tip cooling during radiofrequency ablation of intraatrial reentry: effects on power, temperature, and impedance. J Cardiovasc Electrophysiol 2002;13:783-7. DOI PubMed

51. Kaminer MS, Bogle MA, Alexiades-Armenakas M. In: Hruza GJ, Tanzi EL, editors. Lasers and lights. Elsevier; 2017. Available from: https://www.mea.elsevierhealth.com/lasers-and-lights-9780323480062.html [Last accessed on 2 Dec 2021].

52. Weiner SF. Radiofrequency microneedling: overview of technology, advantages, differences in devices, studies, and indications. Facial Plast Surg Clin North Am 2019;27:291-303. DOI PubMed

53. Hantash BM, Ubeid AA, Chang H, Kafi R, Renton B. Bipolar fractional radiofrequency treatment induces neoelastogenesis and neocollagenesis. Lasers Surg Med 2009;41:1-9. DOI PubMed

54. Chandrashekar BS, Sriram R, Mysore R, Bhaskar S, Shetty A. Evaluation of microneedling fractional radiofrequency device for treatment of acne scars. J Cutan Aesthet Surg 2014;7:93-7. DOI PubMed PMC

55. Harth Y, Elman M, Ackerman E, Frank I. Depressed acne scars-effective, minimal downtime treatment with a novel smooth motion non-insulated microneedle radiofrequency technology. JCDSA 2014;04:212-8. DOI

56. Elawar A, Dahan S. Non-insulated fractional microneedle radiofrequency treatment with smooth motor insertion for reduction of depressed acne scars, pore size, and skin texture improvement: a preliminary study. J Clin Aesthet Dermatol 2018;11:41-4. PubMed PMC

57. Pudukadan D. Treatment of acne scars on darker skin types using a noninsulated smooth motion, electronically controlled radiofrequency microneedles treatment system. Dermatol Surg 2017;43 Suppl 1:S64-9. DOI PubMed

58. Harth Y, Frank I. In vivo histological evaluation of non-insulated microneedle radiofrequency applicator with novel fractionated pulse mode. J Drugs Dermatol 2013;12:1430-3. PubMed

59. Sadick NS, Makino Y. Selective electro-thermolysis in aesthetic medicine: a review. Lasers Surg Med 2004;34:91-7. DOI PubMed

60. Dubinsky TJ, Cuevas C, Dighe MK, Kolokythas O, Hwang JH. High-intensity focused ultrasound: current potential and oncologic applications. AJR Am J Roentgenol 2008;190:191-9. DOI PubMed

61. Fabi SG. Noninvasive skin tightening: focus on new ultrasound techniques. Clin Cosmet Investig Dermatol 2015;8:47-52. DOI PubMed PMC

62. Vaughan MG, ter Haar GR, Hill CR, Clarke RL, Hopewell JW. Minimally invasive cancer surgery using focused ultrasound: a preclinical, normal tissue study. Br J Radiol 1994;67:267-74. DOI PubMed

63. Ghassemi A, Prescher A, Riediger D, Axer H. Anatomy of the SMAS revisited. Aesthetic Plast Surg 2003;27:258-64. DOI PubMed

64. White WM, Makin IR, Barthe PG, Slayton MH, Gliklich RE. Selective creation of thermal injury zones in the superficial musculoaponeurotic system using intense ultrasound therapy: a new target for noninvasive facial rejuvenation. Arch Facial Plast Surg 2007:9:22-9. DOI PubMed

65. Minkis K, Alam M. Ultrasound skin tightening. Dermatol Clin 2014;32:71-7. DOI PubMed

66. Oni G, Hoxworth R, Teotia S, Brown S, Kenkel JM. Evaluation of a microfocused ultrasound system for improving skin laxity and tightening in the lower face. Aesthet Surg J 2014;34:1099-110. DOI PubMed

67. Suh DH, Oh YJ, Lee SJ, et al. A intense-focused ultrasound tightening for the treatment of infraorbital laxity. J Cosmet Laser Ther 2012;14:290-5. DOI PubMed

68. Suh DH, Shin MK, Lee SJ, et al. Intense focused ultrasound tightening in Asian skin: clinical and pathologic results. Dermatol Surg 2011;37:1595-602. DOI PubMed

69. Alam M, White LE, Martin N, Witherspoon J, Yoo S, West DP. Ultrasound tightening of facial and neck skin: a rater-blinded prospective cohort study. J Am Acad Dermatol 2010;62:262-9. DOI PubMed

70. Chen L. $510(\mathrm{k})$ Summary Sofwave Medical's Sofacia System. U.S Food \& Drug Administration. Available from: https://www.accessdata.fda.gov/cdrh_docs/pdf19/K191421.pdf [Last accessed on 2 Dec 2021]. 
71. Chan NP, Shek SY, Yu CS, Ho SG, Yeung CK, Chan HH. Safety study of transcutaneous focused ultrasound for non-invasive skin tightening in Asians. Lasers Surg Med 2011;43:366-75. DOI PubMed

72. Alhaddad M, Wu DC, Bolton J, et al. A randomized, split-face, evaluator-blind clinical trial comparing monopolar radiofrequency versus microfocused ultrasound with visualization for lifting and tightening of the face and upper neck. Dermatol Surg 2019;45:131-9. DOI PubMed 